\title{
新聞記事分析による東北地方太平洋沖地震時の 住民の津波避難行動
}

\author{
森 伸一郎 1 ・鵜久森 潤2 \\ 1フェロー 愛媛大学准教授 大学院理工学研究科（†790-8577 愛媛県松山市文京町3） \\ E-mail: mori@ehime-u.ac.jp \\ 2学生会員 愛媛大学 大学院理工学研究科（干790-8577 愛媛県松山市文京町3） \\ E-mail: ugumori.jun.08@cee.ehime-u.ac.jp
}

\begin{abstract}
2011年3月11日の東北地方太平洋沖地震では, 広範囲で極めて甚大な人的・物的被害が生じた. 人的被 害の99\%超が津波による。津波リスクに対する住民の避難行動の実態を知り，その特徴と避難の正否から 見た問題点を明らかにするために，津波避難行動に関する509件の新聞記事を収集し，内容分析に基づい て，岩手県，宮城県の住民の津波避難行動形態と地域・生死・男女について統計的に分析した。 その結果， 生死別の比較から，事前避難の有効性が確認され防災活動中の切迫避難の死亡リスクが両県で際立って高 かった．地形と津波歴史の異なる両県で避難行動に大きな違いがあった．また男女別の比較から, 男性で は両県で避難前防災活動が最多である一方，女性では岩手で用事後避難，宮城で切迫避難が最多であった。
\end{abstract}

Key Words : tsunami, evacuation behavior, newspaper article,content analysis, Great East Japan Earthquake

\section{1. はじめに}

2011年3月11日に発生した東北地方太平洋沖地震によ る地震動と地震により引き起こされた津波により，東日 本の太平洋沿岸の都市集落に壞滅的な被害が生じ，東日 本大震災と名付けられる未曾有の災害となった。 なかで も，岩手，宮城，福島の3県では，2012年9月12日現在で 死者・行方不明者は 18,614 人に及び，全ての人的被害の $99.6 \%$ 占めた ${ }^{11}$ ．その内，死者の $92.4 \%$ の死因が津波に よる溺死であった.

岩手，宮城の両県をまたぐ三陸地方は，歴史的な背景 からも津波常襲地帯と認識され，津波に対する防災意識 は他地域よりも高く, 津波避難原則は浸透していたと考 えられていた．また，明治・昭和の三陸地震津波とは異 なり，地震と津波に関する基礎的知識は流布され，津波 警報が発表される体制にあった，すなわち，明治・昭和 の三陸津波と異なり, 知識・情報の両面から津波リスク として認識され得た状況下での人的被害である.このよ うな観点から，甚大な人的被害になった原因を明らかに するためには，津波リスクに対する住民の避難行動の実 態を調べ，問題点を明らかにする必要がある.

津波避難行動に関する調査の方法として，アンケート 調査やインタビュー調査2) などが考えられる. 一般に, 自然災害の現場では，防災行政，報道機関，研究機関に
よる現地調査が重複することなどによって，被災地域や 被災住民が迷惑と感じる「調查公害」が危惧される，さ らに，今回の津波災害は人的・物的被害が甚大・悲惨で あるため, インタビュー調査は高度なデリカシーを必要 とする. また, 死亡・行方不明者の避難行動を調查する ことも様々な理由から容易ではない，被災領域があまり に広いため全域をカバーすることは困難である。これら の理由から津波避難行動に関する研究目的の現地調査は 容易ではないと判断した.

そこで，直接面談したり調査したりするのが難しい 人々を対象とした調査に向いている内容分析 ${ }^{3)}$ を新聞や 体験談などに適用することを考えた，地方紙・全国紙を 対象にして, 津波避難行動に関する新聞記事を徹底収 集・整理して，その内容分析に基づき，今回の津波に対 する住民の避難行動の実態を統計的に検討することを目 的とした. また，津波で亡くなった方や行方不明になっ た方の津波避難行動について記述されている記事も少な くないために, 他の調査では得難い内容が含まれている のが大きな特徵である.

新聞記事の内容分析は，20世紀に入り始まり，急速に 進展した ${ }^{4}$. 内容分析とは，データを基にそこから文脈 に関して再現可能でかつ妥当な推論を行うための一つの 一技法であり ${ }^{4)}$ ，コミュニケーション・メッセージの諸 特性を体系的, 客観的にとらえるための主として数量的 
な処理を伴う手続きである゙ 。研究結果が妥当であるた めには，信頼性は必要条件であり，妥当性は十分条件で ある4). そして, 内容分析の結果の妥当性検証をいい加 減にしないために, 妥当性の概念的枠組みを整理して示 すことを目的として妥当性が類型化されだ)。妥当性は, 内的妥当性 (信頼性) と外的妥当性（妥当性そのもの） に分けられ，外的妥当性はデータ連関妥当性，結果指向 的妥当性, 過程指向妥当性の3種に類型化して, さらに それらの下位概念として5種の妥当性に類型化している 4) . 避難行動記事を対象に内容分析寸るに当たり, この 文脈で述べられている妥当性を念頭に置いた。

内容分析は新聞記事を対象として提案・適用されてき た歴史的背景を考えても，新聞記事を用いた分析はこれ までも多く行われてきた，災害とメディアの関係に関す る研究は，メディアがどのような災害情報を流し，住民 の心理的反応を調べるの, わという内容のものが多い，新 聞などの報道はメディアという媒体による情報であるた め, 現地での各調査と比較すると「ずれ」や「隔たり」 が生じることがある.そのような新聞報道と実調査を比 較し傾向を分析したもの ${ }^{8)}$ や，過去の災害においてもテ キストマイニングを用いた傾向分析に用いられた事例9) が多い.しかし, 新聞記事から避難行動を分析した例は, 五味・葛葉10)など少ない.

本論文では，新聞記事をドキュメントとして内容分析 の結果に統計的検討を加え，これまでに著者らが検討し てきた地域別 ${ }^{11)}$ や男女別 ${ }^{12)}$ の避難行動の差異, 岩手県で の生死別避難時期 ${ }^{13)}$ の差異などを基礎として, 新聞間の 統計的な比較分析から各新聞の編集意図による記事の偏 りについても検討を加えて, 岩手・宮城両県についてそ れらの避難行動の特徴を明らかにする.

\section{2. 津波避難行動に関する新聞記事と分析}

\section{（1）研究方法の背景と方針}

新聞記事は，ドキュメント分析に耐えられる材料と考 えられる. その分析方法の背景として, 社会学や心理学 などの分野での社会調查法の1つである内容分析で考え ておくべき事項を整理し，方針を明らかにしておく.

ティム・メイ ${ }^{14)}$ は，ジョンスコット(1990)が情報源と してのドキュメントについて，その証拠の質を評価とす る基準として, 真偽, 信憑性, 代表性, 意味の4つの基 準を掲示していることを紹介している.

第一に，この形態の調査で本質的である真偽の基準と しては，プラット(1981)による7つの指針を示している.

第二の信憑性は証拠の歪曲，偽り，誤り，ごまかしの ない程度を指す。

第三に，代表性を典型性の問題として示しており，本
研究のように，新聞記事を扱う際には念頭に置くべき基 準であると考えられる. 寸なわち, 新聞では, 記者によ る話者のナラティブの選択と編集者による記事の選択と いう2段階の取捨選択がなされている，そのために，新 聞を構成する記事やその集合体が津波避難行動に関わる 被災地の人々の行動を代表しているかどうかという代表 性の問題がつきまとう. したがって, サンプル数の十分 さとサンプルの属性構成などでサンプルの代表性を担保 することが重要である.

最後に，ドキュメントの意味という問題は，「それは 何か，また，何を教えてくれるか」という点でのドキュ メントの明晰さと理解しや寸さであり, 先行研究から引 き出された社会の文脈に置かれていると述べている. す なわち, 判断と態度決定と行動の様式は, 体験談やイン タビューでのナラティブ分析では, 重要な意味を持つ. 避難行動新聞記事に書かれる短い内容では行動の事実の 記述に重点が置かれ，その行動の原因については記者の 取捨選択がなされている可能性があるが，行動の事実を 分析するという本研究の目的を考えれば，意味は明白で ある.

これらのことを考慮して避難行動記事分析を考える. ある地域内の住民避難行動の背景となる地域事情を知る には，地域の地方紙が有効と考えられるが，その地域一 の偏りがある. 一方, 全国紙は全国をカバーするため各 地方を全国の視点で相対化する．被害実態を反映しない 特定地域一の偏りは避けられる反面, 地域外からの応援 記者による体系のない取材や土地勘や地域事情に通じな い理解での記事になる可能性があり，さらに中央編集者 による特定の方針で編集される可能性がある. したがっ て，全国紙と地方紙の両方を併せ見ながら，主に個々の 記事の内容の深さで勝る地方紙の記事をサンプルとして その地方の住民の避難行動を分析する.

\section{（2） 津波避難行動記事の収集・整理の方法 a) 分析対象の新聞}

上述の方針に基づき，代表性のある津波避難行動に関 する新聞記事の掲載が期待できない原発事故の起きた福 島県を外し, 主に岩手県と宮城県の住民の避難行動につ いて調査することを目的とした，サンプルにおける記 者・編集者のバイアスという観点とサンプルの代表性と いう二つの観点から, 地元の被災者目線を意識し詳細で 多数のサンプルが期待される地方紙 2 紙（岩手日報およ び河北新報）と被災地以外の読者をも意識した客観的視 線と選択的構成が予想される全国紙2紙（読売新聞およ び朝日新聞）の合計4紙（以下，4紙とする）を対象とし た.

本論文では，特に避難行動記事の記事分析から一般化 される結論が得られるかどうかというサンプルの代表性 
という観点を重視する.

\section{b) 分析対象の新聞の媒体}

新聞記事を利用した最近の調査の多くは，古いもので あれば有料で利用可能な新聞データベース，リアルタイ ムではインターネット web 版の新聞記事を対象に調査 している．しかし，本研究で対象とする地方紙では，実 際に紙媒体の新聞を購読し, web 版と比較したところ, web 版では紙媒体で取り扱った全ての新聞記事が掲載さ れているわけではなく, 取り扱っているのは特集企画記 事か，いくつかの一般記事だけであった。 そのため，紙 媒体の新聞を年間購読し，その全ての新聞記事の中から, 避難に関する記事を見つけ出すということとした.

\section{c） 津波避難行動記事の定義}

各新聞から, 地震当日に津波の浸水地域またはその周 辺にいた住民の地震後の避難行動が記述されている記事 を探し出す，着目した記事では，記者がインタビューし た人物の属性や行動，その家族や見聞きした他人の行動， それ以外の復興などに関する内容が記述されている段落 を併せたものを津波避難行動記事と定義する.

\section{d）津波避難行動記事の収集と整理}

新聞から津波避難行動記事を見つけ出し，収集対象と する記事の見つけ出しは，第1著者によった．地震直後 の津波避難行動を述べた一般記事，津波避難や仮設住宅 生活，復旧・復興などに焦点を当てた企画記事などは見 つけ出しは容易いが，その他の題名が付いた記事や家 庭・生活欄の津波避難とは異なる企画記事などのように 避難行動が記載されていることが期待されない見出しの 記事でも避難行動が記述されている場合も少なくない. したがって，津波避難行動記事を見落としなく収集する ためには，ほぼ全ての記事に目を通すという負荷の高い 作業となるためである.

次の作業は定義した避難行動記事に該当寸る部分の抽 出である. 見つけ出された記事から, 避難行動に加えて 避難主体の属性などが記述された段落が避難行動の記述 された段落から離れている場合も少なくない．この避難 行動記事の抽出と全文を入力寸る作業は第2著者によっ た. 新聞の web 電子版に掲載された記事の採取であれ ば負荷は軽減できると考えられるが，現在，多くの新聞 で，必ずしも全ての紙媒体の記事が電子化されて web で提供されていないことを確認したため，新聞の電子版 に頼らず，全て紙媒体によっている.

ドキュメント分析の基礎とするために，新聞に関する 属性と記事内容の生データに加えて, 後に述べる分析項 目を統計分析しやすくするために MS-Excel を用いて津 波避難行動記事データベースとして整理した.

\section{e）津波避難行動記事の分析項目}

津波リスクに対する避難行動では，個人としての行動 のほか家族・組織などの集団での行動が考えられるので,
人または同じ行動をとった集団を避難行動主体と定義し， その行動主体を単位として分析した.

分析項目は，属性12項目，行動16項目である. 記事か ら各項目に対応することを読み取るが，文字として記述 されていない項目を文脈や常識から読み取ることもでき るため，読み取りは日本語の習熟度に依拠する．第2著 者が分析してデータベースに入力し，その結果を 2 人の 著者で確認した.

\section{f）収集・整理の作業時間}

岩手日報では，最初の1ヶ月間は，1日の新聞から避難 行動に関する記事を集めるために2時間かかり，分析と データベース化に2時間かかった，そのため全ての新聞 に対して1年間を対象にすることは2人で行う作業時間の 面から大きな制約となる.

そのため，サンプルにおける記者・編集者のバイアス という観点とサンプルの代表性という二つの観点から検 討することに目的を限定し，他の新聞では最初の1ヶ月 に限定した.

\section{g) 分析対象の期間}

岩手日報（岩手県の地方紙）は購読により2011年3月 12日から2012年3月11日の1年間を，河北新報（宮城県の 地方紙），読売新聞および朝日新聞については特別縮刷 版（発生当日から1力月）を利用した．特別縮刷版は， 東日本大震災に関する記事のみを掲載したもので，調査 の効率性を考えてのことである.

収集期間によりデータセットの有意な差異の有無につ いて統計的な検定が必要であり，本論文では検定する. 新聞記事分析では，個別の新聞社の編集方針によるメ ッセージ性の強い特定の編集意図（例えば，避難しない という行動や防災活動後に切迫避難するという避難行動 形態に対する注意喚起を図る，など）により実態に対し て偏ったデータセットになっている可能性がある.した がって, 複数新聞社間の統計的な比較分析を行い, 偏り の有無について検討することが必要である．本論文では， この点を検討して分析する.

\section{（3）新聞の避難行動記事のドキュメント分析の例}

新聞の避難行動記事のドキュメント分析を例示寸るた め，岩手日報の2011年5月22日（日）号26面掲載の「水 産のまち 再興の鐘」という企画記事内の避難行動記事 を以下に示す。

「カランカラン、カランカラン」。甲高い鐘の音が始 まりの合図を告げた。小気味よく競りの掛け声に、買い 受け人の声が重なる。大船渡市大船渡町の大船渡魚市場 （菅野佑三社長）。競り人を担当したのは入社 9 年目の 業務部及川将さん(26)=同市大船渡町=だ。

3月11日。同市末崎町の第2市場でイサダの水揚げを終 
え、建物内にいた。経験したことのない激しい摇れが全 身を襲った。外の岸壁が大きくうねるように見えた。

「車で上がれ」。上司に促され、高台へと急いだ。

鳴り響く防災無線とサイレン。波は湾口防波堤をあっ

という間に乗り越え、家々をのみ込んだ。「信じられな

い」。ぼうぜんと立ち尽くすしかなかった。

この記事に基づいて，属性12項目，行動16項目からな る分析項目と読み取り内容を以下に示寸。

\section{【主体の属性】}

氏名（主体の代表者名）：及川将

[1] 年齢（主体代表者の年齢）：26歳

[2] 性別（主体代表者の性別）：男

［3］社会的立場（主体代表者の立場）：漁師

４］地震時にいた社会的場所 : 職場

[5]地震時に一緒にいた人：上司（および同僚）

[6] 地震時にいた地点の県名 : 岩手県

[7] 地震時にいた地点の市町村名 : 大船渡市

[8] 地震時にいた地点の町村, 地区名 : 末崎町

[9] 地震時にいた地点の詳細な場所 : 第2市場

[10] 主体に含まれる行動者数 : 1名（とした）

[11] 記事掲載時の主体の属性 : 被インタビュー者

\section{【避難行動】}

[1] 避難の有無 : 避難した

[2] 避難の成否 : 避難成功

[3] 避難行動の結果（生/死）：生

[4] 避難開始のきっかけ：呼び掛け（上司の指示）

[5] 避難開始の時期 : 地震直後

[6] 最初に避難しようとした場所 : 高台

[7] 避難した場所 : 高台

[8] 避難した建物の階数 : 該当せず

[9] 避難手段 : 車

[10] 避難しなかった理由 : 該当せず

[11] 津波に遭遇した場所 : 該当せず（遭遇なし）

[12] 被災の度合い: 津波で濡れていない, 無傷

[13] 自宅で遭遇した場合 : 該当せず

[14] 避難行動の種類 : 直後避難

[15] 避難呼び掛け（する/される/両方/なし）：される

[16] 避難呼び掛けの種類 : 直接

項目の設定で，属性には，他の調査方法と同様な項目 として，主体の属性や地震時の（地理的）場所などがあ る $[1,2,6,7,8,9]$.

そのほかに，次に述べる3項目を新たに加えた．森 ${ }^{15}$, 森・松浦 ${ }^{10}$ によるチリ地震時の津波避難行動調查の結果 では，男女により避難のきっかけに違いがあり，男性は
社会的立場により結果的に自身も避難し，女性は呼び掛 けにより避難したという，性別と社会的立場の影響があ ることがわかっていることから，「社会的立場」を加え た.

また，これを考慮して，地震時にいた場所は，地理的 場所というだけでなく，社会的立場の影響を強く受ける 可能性があるという観点から，「社会的場所」（造語, 職場, 学校ほか) も新たに加えた. 例えば, 学校であれ ば生徒は先生の指示に従って動き, 職場であれば上司の 指示に従って動くことが多いと考えられるからである.

同様の観点で，主体の社会的な立場や地震時に一緒に いた人との相対的立場が自身の避難に影響したと考えら れることから，「地震時に一緒にいた人」も加えた.

次に，避難行動の項目であるが，全ての項目が読み取 れる訳ではないので, 属性とは異なり, インタビュ一調 查 ${ }^{20)}$ やアンケート調查などで調查可能な項目より限定的 であるために，多くの新聞記事で読み取れる程度の項目 に絞っている.

\section{（4）避難行動の時期による分類}

本論文では，避難を「災害リスクに対して事前に安全 な場所に逃れること」と定義する.リスクは危害が発現 寸る前であることを特徴としており，津波を見る前に起 こした避難行動こそが避難である.津波を目の当たりに してからの避難である切迫避難は，危害が発現する前と は言え, その確率は客観的には限りなく1に近い, 切迫 避難は客観確率が極めて1に近く，これを避難に含めた 分析結果が読者をミスリードする懸念が払拭できないと いう理由から，分析結果を検討寸る際には避難に含めな い.

避難行動時期による分類は, 内閣府, 消防庁, 気象庁 (以降は，内閣府等と記す）が共同で行なった避難行動 調查 ${ }^{2}$ の分類を参考にし, 以下に定義される7つとした.

[1]「直後避難」=「地震の摇れがおさまった直後にす ぐ避難した」

[2]「用事後避難」=「摇れがおさまった後, すぐには 避難せずなんらかの行動を終えて避難した」

[3] 「防災活動後避難」=「摇れがおさまった後, 避難 誘導などの防災活動を行なって避難した」

[4]「切迫避難」=「摇れがおさまった後, すぐには避 難せずなんらかの行動をしている最中に津波が迫つ てきて逃げた」

[5]「防災活動中切迫避難」=「摇れがおさまった後, 避難誘導などの防災活動を行い，その最中に津波が 迫ってきて逃げた」

[6] 「避難していない（避難せず）」＝「避難が必要だ ったが避難せず津波に遭った」

[7]「避難の必要がない」=「地震時に避難の必要がな 
表-1＼cjkstart新聞別の避難行動記事の収集状況と岩手，宮城，福島県の諸情報

\begin{tabular}{|c|c|c|c|c|c|c|c|c|c|}
\hline & \multirow{2}{*}{ 収集期間 } & \multirow{2}{*}{ 記事件数 } & \multirow{2}{*}{ 主体数 } & \multicolumn{3}{|c|}{ 構成割合（\%） } & \multicolumn{3}{|c|}{ 主体数/死者・行方不明者(\%) } \\
\hline & & & & 岩手県 & 宮城県 & 福島県 & 岩手県 & 宮城県 & 福島県 \\
\hline \multirow{2}{*}{ 岩手日報 } & 1年 & 262 & 348 & 89.2 & 9.6 & 0.6 & 5.36 & 0.31 & 0.11 \\
\hline & 1力月 & 62 & 95 & 81.1 & 16.8 & 2.1 & 1.31 & 0.15 & 0.11 \\
\hline 河北新報 & 1力月 & 97 & 123 & 18.7 & 80.5 & 0.8 & 0.39 & 0.91 & 0.06 \\
\hline 朝日新聞 & 1力月 & 91 & 149 & 42.6 & 39.2 & 18.2 & 1.07 & 0.53 & 1.49 \\
\hline \multirow[t]{4}{*}{ 読売新聞 } & 1力月 & 59 & 89 & 48.3 & 46.1 & 5.6 & 0.73 & 0.38 & 0.28 \\
\hline & \multicolumn{3}{|c|}{ 人口 } & \multicolumn{3}{|c|}{ 死者・行方不明者 } & \multicolumn{3}{|c|}{ 死者・行方不明者/人口(\%) } \\
\hline & 岩手県 & 宮城県 & 福島県 & 岩手県 & 宮城県 & 福島県 & 岩手県 & 宮城県 & 福島県 \\
\hline & $1,326,643$ & $2,348,165$ & $2,024,401$ & 5,876 & 10,921 & 1,817 & 0.44 & 0.47 & 0.09 \\
\hline
\end{tabular}

い高台などにいた」。

\section{（5） グループ間の比率の差の検定}

男女別や生死別など二つのグループ間の差異の有意性 を論じるため，2項分布の正規近似による比率の差の検 定 ${ }^{17}$ を行う．2つの母比率を $\pi_{1}, \pi_{2}$ の相等性を検定す る.このとき $H_{0}$ を帰無仮説， $H_{1}$ を対立仮説とすると，

$$
\begin{aligned}
& H_{0}: \pi_{1}=\pi_{2} \\
& H_{1}: \pi_{1} \neq \pi_{2}
\end{aligned}
$$

検定には次の式を用いた.

$$
Z=\frac{p_{1}-p_{2}}{\sqrt{p_{1}\left(1-p_{1}\right) / n_{1}+p_{2}\left(1-p_{2}\right) / n_{2}}}
$$

ここで, 確率変数を $Z$, 標本比率を $p$, 標本数 $n$ で ある，検定は，両側検定で，有意水準を5％とするため， 確率変数 Z が Z $>1.96$ の場合，帰無仮説は棄却され，有意 差がある．以下の考察では，Zの值を付記する。

なお，比率の差の検定では，正規母集団から抽出され たサンプルとして標本分散を求めるが，母分散 $\sigma^{2}$ は不偏 推定量 $\mathrm{U}^{2}$ の期待值 $\mathrm{E}\left(\mathrm{U}^{2}\right)$ として求められるので，標 本分散を $S^{2}$ と寸ると， $\sigma^{2}=n S^{2} /(n-1)$ によって求められる。 その適用には標本数が25以上であれば正規近似で正確で あるとされている．そのため，この標本数が25未満につ いては検定の信頼性にが十分ではないことに留意が必要 である.

\section{（6） 避難行動記事の時間的推移}

表-1に新聞別の避難行動記事の収集状況と岩手，宮城 福島県の諸情報を示す 11 , 18), 19), 20)，岩手日報で262件，4紙 合計509件である。構成割合は各新聞の避難行動記事か ら読み取った主体が地震時にいた県の割合である。1ケ 月間の構成割合でみると，岩手日報は岩手県を $81.1 \%$, 河北新報は宮城県を $80.5 \%$ の割合で取り扱っており，主 体数/死者・行方不明者数の割合をみても，岩手日報で $1.31 \%$ ，河北新報で0.91 \%と高くなっているため，地方

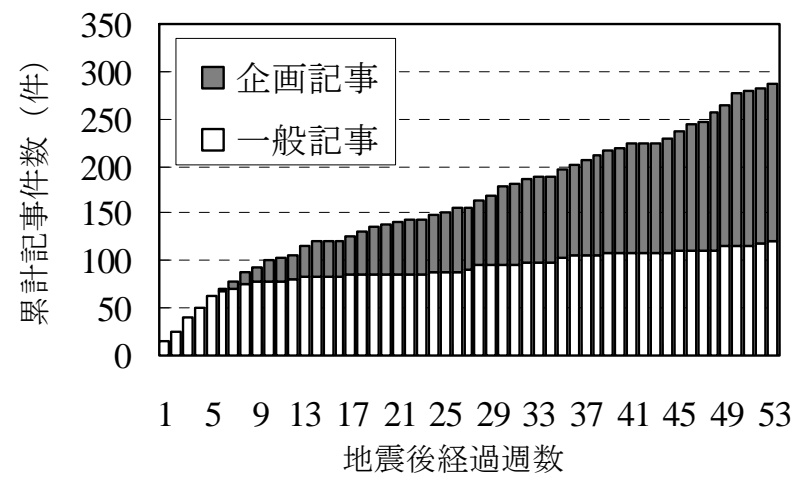

図-1＼cjkstart岩手日報における 1 年間の避難行動記事の累 計記事数

紙では自地域をより多く掲載する傾向がある．朝日新聞 と読売新聞においては，岩手県と宮城県の構成割合の比 は $1: 1 て ゙$ 取り扱っている. 死者・行方不明者数/人口の

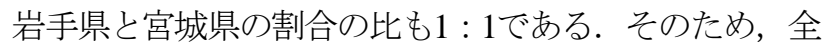
国紙は岩手県と宮城県を同程度ずつ掲載しており，死 者・行方不明者数 /人口を考慮していると考えられる.

福島県は，主体数/死者・行方不明者数の割合が朝日 新聞が1.49 \%と他の新聞より高いが，構成割合は相対的 に小さい，福島県に関する記事は，原発事故関連記事に 占められため，福島県の津波避難記事が少なくなったも のと考えられる.

図-1に岩手日報に掲載された避難行動記事の週単位の 累積記事件数の推移を示寸. 企画記事とは7種の連載企 画記事である，週当たり記事数の平均は，地震後2力月 までは約11件であるが，それ以降は約4件とペースが落 ちている。 その内訳は，一般記事で0.7件，企画記事で 3.3件であり，ある個人や地域に注目した企画記事では， 地震時の行動抜きには語れないことが多いと推察される. 結果として2ヶ月以降に全数の約7割を占める.

図-2に地震後1力月間に4紙に掲載された避難行動記事 の日単位の累積記事件数の推移を示寸. 岩手日報と読売 


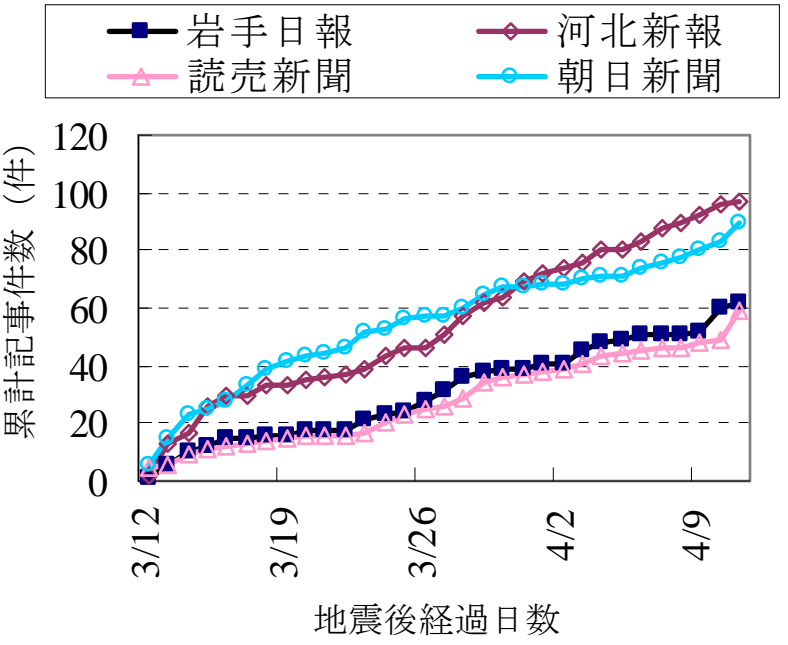

図-2＼cjkstart地方紙・全国紙 4 紙における 1 ケ月の避難行動 記事の累計記事数

新聞に関してはよく似た傾向を示している，河北新報と 朝日新聞は地震後1週間は似た傾向を示しているが，そ の後，3月末までは朝日新聞が避難行動記事の累積記事 件数が多く，4月に入ってからは河北新報の累積記事件 数が朝日新聞を上回っている. 河北新報以外の新聞に共 通しているのは，地震後1ヶ月付近においてそれまでよ りも記事件数の増加の傾向が大きくなっていることであ る. また, 日あたりの平均文字数は岩手日報は645字, 河北新報は619字, 読売新聞は718字, 朝日新聞は1049字 であった．朝日新聞を除いた3紙はよく似た傾向を示し ており，日あたりの平均文字数にも大きな差はない．朝 日新聞は累積記事件数が多い分, 累積文字数も多くなっ ているが，河北新報は累積記事件数が多いものの, 累積 文字数は少ない. 記事あたりの文字数は岩手日報322字, 河北新報198字, 読売新聞378字, 朝日新聞369字であっ た.

\section{3. 新聞記事による岩手県住民の津波避難行動}

\section{（1）岩手日報の避難行動記事の標本の特性}

\section{a) 性別と年齢の構成比}

男女と年齢の構成比に着目して標本の特性を述べる. 津波避難行動記事の対象は岩手県沿岸部12市町村である. そこで，2010年国勢調査に基づき岩手県沿岸部12市町村 を合計したものを対象とする。

図-3に (a) 国勢調査に基づく対象地域と (b) 津波避難行 動記事（岩手日報）における標本の男女構成比を示寸. 前者が5:5であるのに対して，後者は6:4となっており， やや男性側に偏った標本である. 一方, 後述の内閣府等 調査の男女構成比は4:6となり, やや女性側に偏った標

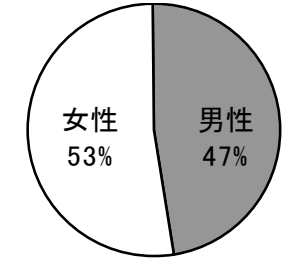

(a) 国勢調査

$(\mathrm{N}=272,937)$

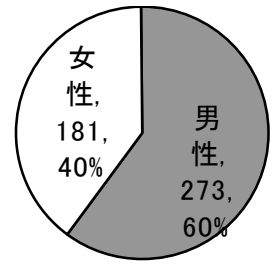

(b) 津波避難行動 記事( $\mathrm{N}=322)$
図-3 岩手県の沿岸部 12 市町村の男女構成比

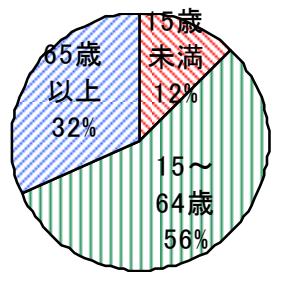

(a) 国勢調査 ( $\mathrm{N}=273,940)$

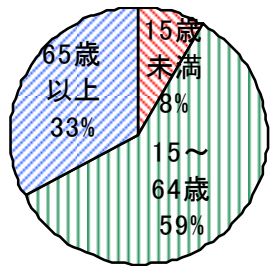

(b) 津波避難行動 記事 $(\mathrm{N}=278)$
図-4 岩手県の沿岸部 12 市町村の年齢別構成比

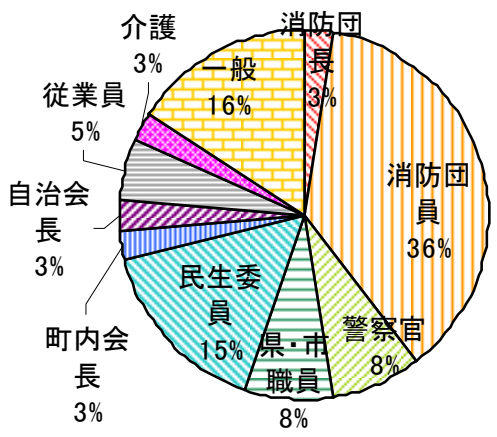

図-5 津波避難行動記事における岩手県の防災活動を 行なっていた主体の構成比（N=38）

本である.したがって，男女差については，この2つの 標本の違いを念頭に置く必要がある.

図-4に (a) 国勢調査に基づく対象地域と (b) 津波避難行 動記事（岩手日報）における標本の年齢別構成比を示す. 標本の15歳未満8 \%が母集団の $12 \%$ と比べてやや低くな っているものの概ね実際の構成を反映している. 一方, 後述の内閣府等調查の年齢構成比は，国勢調査の年齢構 成の区分が異なっているため，この点の妥当性を検討す ることができない.

\section{b) 防災活動を行なっていた主体の社会的立場}

避難誘導などの防災活動に従事していたものは消防団 とは限らない. しかし, 消防団員の犠牲者が多かったこ とが話題となった. 図一5に岩手県における防災活動を行 なっていた主体の社会的立場を示す．消防団に属する者 は約4割であり，それ以外が約6割を占めることは注目に 值する. 


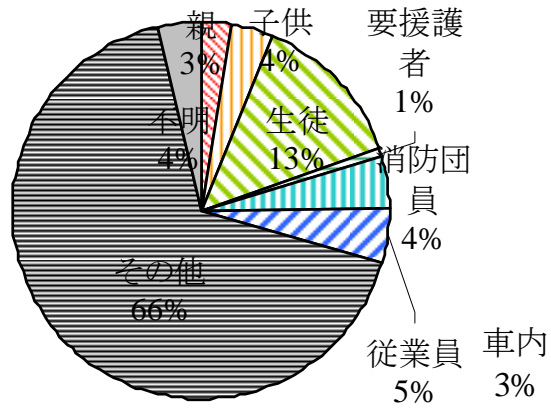

(a) 社会的立場

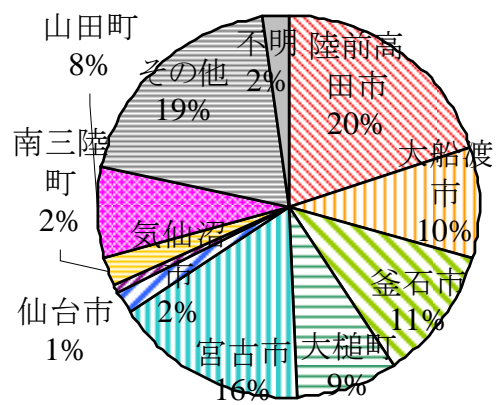

(d) 地震時にいた地域の市町村名

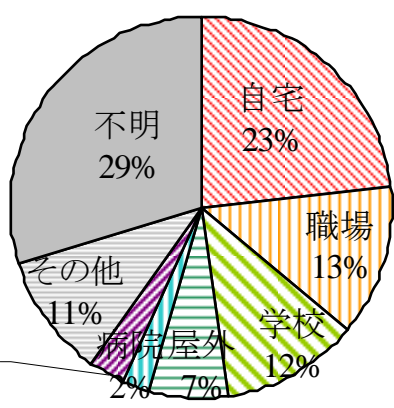

(b) 地震時にいた場所

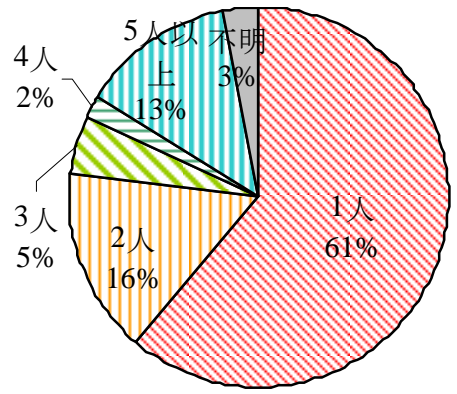

(e) 主体に含まれる行動者数

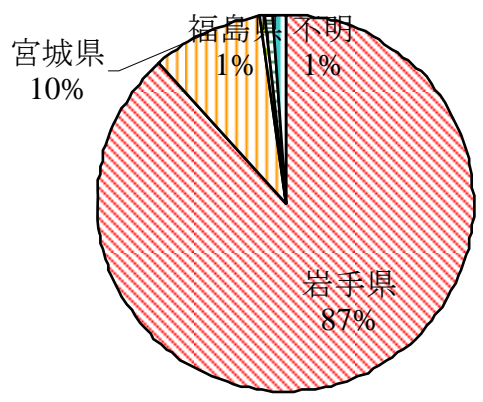

(c)地震時にいた地域の県名

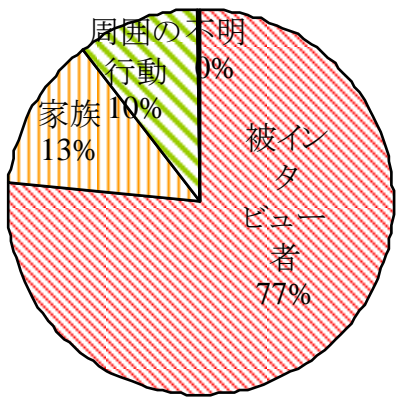

(f) 記事掲載時の主体の属性

図-6＼cjkstart岩手日報に掲載された岩手県内の避難行動記事に掲載された主体の属性（全て $\mathrm{N}=357 ）$

\section{c) 他の属性}

岩手日報に掲載された記事から読夕取った全分析27項 目の内，既に上述したものを除く集計結果を，属性に関 する6項目（8, 9は除く）を図-6に示す。困中の「不明」 は，新聞記事によっては読み取れなかったものであり，

「不明」を除いた割合が全記事からその項目が読み取れ た割合である。

主体の属性に関しては, 県名や市町村名, 行動者数な どはほぼ全ての記事から読み取ることができた。しかし， 場所に関しての詳細な情報である地震時にいた場所の読 み取り率は71\%であり，県名などと比べると低い.

また，岩手県内（自県）の記事を掲載する傾向が高く， その中でも人口に対する死者・行方不明者数の割合の高 い陸前高田市(20\%)や大槌町(9％)や人口の多い宮古市 (16\%)や大船渡市(9\%)，釜石市(11\%)の割合が多い.

主体に含まれる行動者数は，61\%が「1人」で，36\%が 2人以上であり，不明は3\%（学校，職場，商業施設な じ）である.

記事掲載時の主体の属性は「被インタビュー者」（イ ンタビュイー）が77\%であり，主に生き残った方の行動 として読み取ることができる. 残りの $23 \% の$ 記事はイン タビュイーが家族・知人・隣人・他人の避難行動を語つ ており，生き残った方と亡くなった方の行動を読み取る ことができる.

\section{d) 避難行動に関する分析項目}

避難行動に関する分析項目については，避難行動に関 するもの（8，13は除く）の集計結果を図-7に示す．約7 割以上の高い割合で読み取ることができたものは，避難 の有無，避難行動の結果，被災の度合い，避難行動の種 類，避難の成否である。これらは，避難行動分析をする 上で最も基本的な項目である，以上を総括すると，読み 取れた割合が多いのは避難行動の開始・終了時に認知で きる行動の事実項目であると言える.

次に読み取れた割合が半数程度であるのは，避難開始 のきっかけ，最初に避難しようとしていた場所，避難し た場所，避難手段である．避難行動の開始以降の心理と 事実認識であると言える.

一方，半数末満しか読み取ることができなかったもの は，避難開始の時期，避難しなかった理由，津波に遭遇 した場所，避難呼び掛け，避難呼び掛けの種類である. 呼び掛けについては，無ければ記事に現れないことを考 慮すると，読み取ることのできない項目は避難行動中の 心理や時空間の情報であると言える.

したがって，読み取り易い項目は，避難行動の開始・ 終了時の心理と行動の事実認知に関する項目であり，逆 に読み取りにくい傾向にある項目は，避難行動開始後の 自己の心理と時空間に関する事実認識に関する項目であ る.ただし，インタビュイーが覚えていなかったのか記 


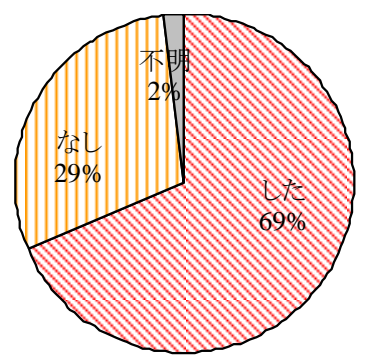

(a) 避難の有無

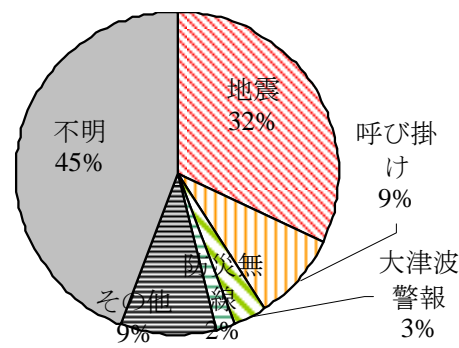

(d) 避難開始のきっかけ

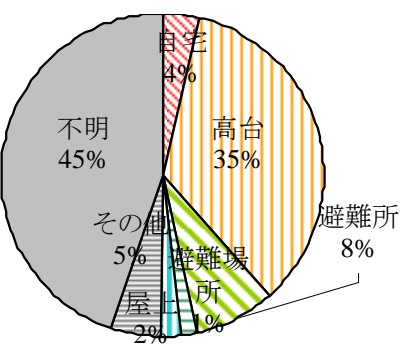

(g)避難した場所

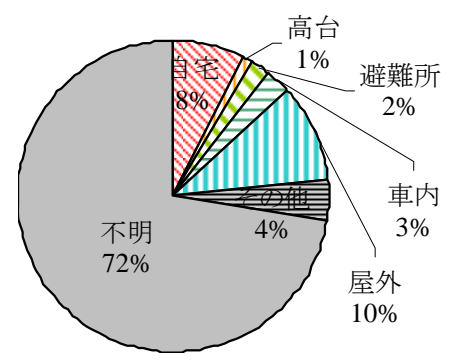

(j)津波に遭遇した場所

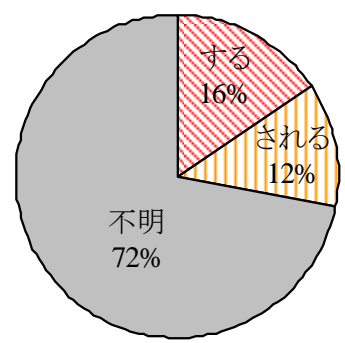

(m) 避難呼び掛け

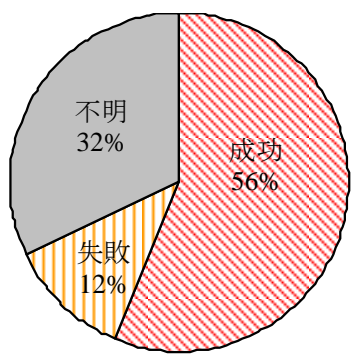

(b) 避難の成否

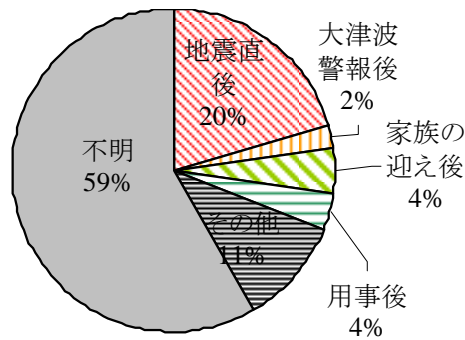

(e) 避難開始の時期

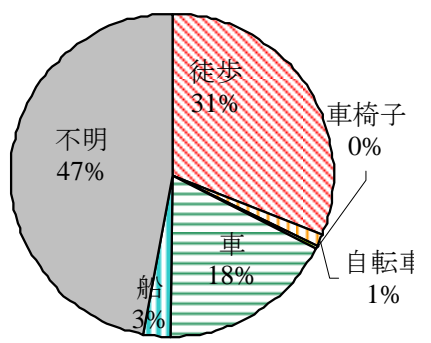

(h) 避難手段

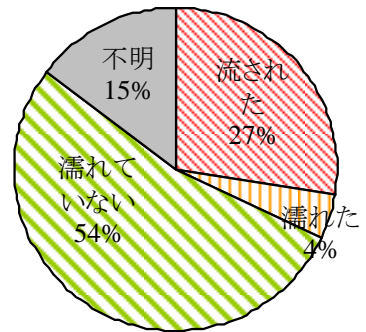

(k) 被災の度合い

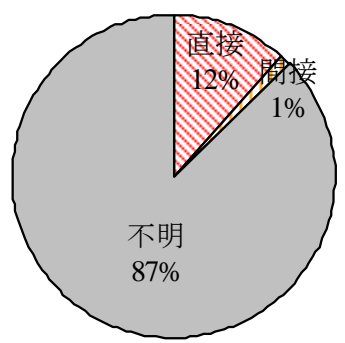

(n)避難呼び掛けの種類

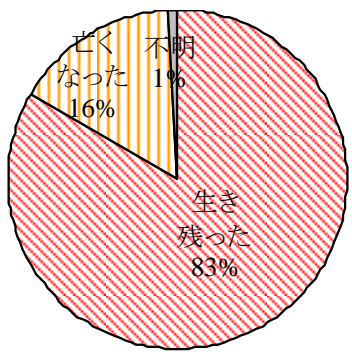

(c) 避難行動の結果

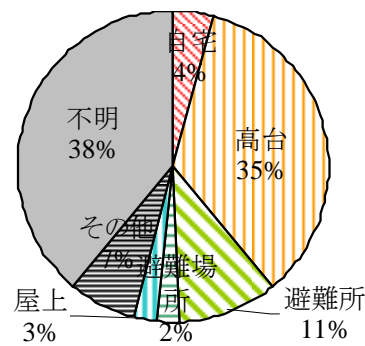

(f)最初に避難しようとした場所

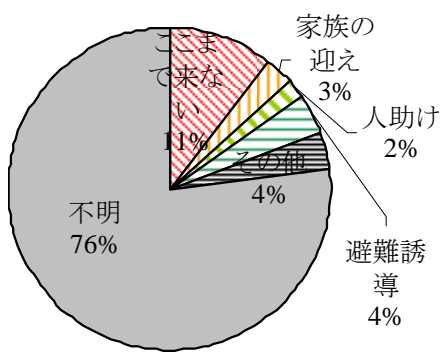

(i)避難しなかった理由

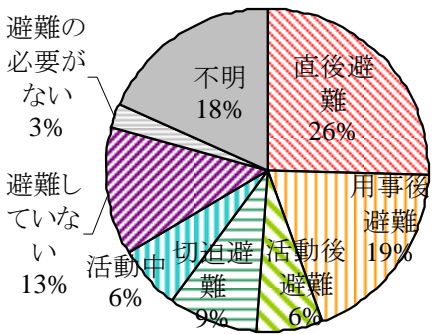

(I)避難行動の種類

図-7 岩手日報に掲載された岩手県内の避難行動記事に掲載された主体の避難行動（全て N=357）

\section{者が取り上げなかったのかという可能性がある.}

\section{（2）岩手日報と他新聞との比較}

避難行動記事の収集期間が，岩手日報（1年間）と他
の3紙（1ヶ月間）とでは異なる．新聞間のデータセット の違いとともに同じ新聞でも異なる収集期間でのデータ セットの違いで生じる可能性のある母集団の統計分析結 果の違いを検討する必要がある，そのため，図-8に岩手 


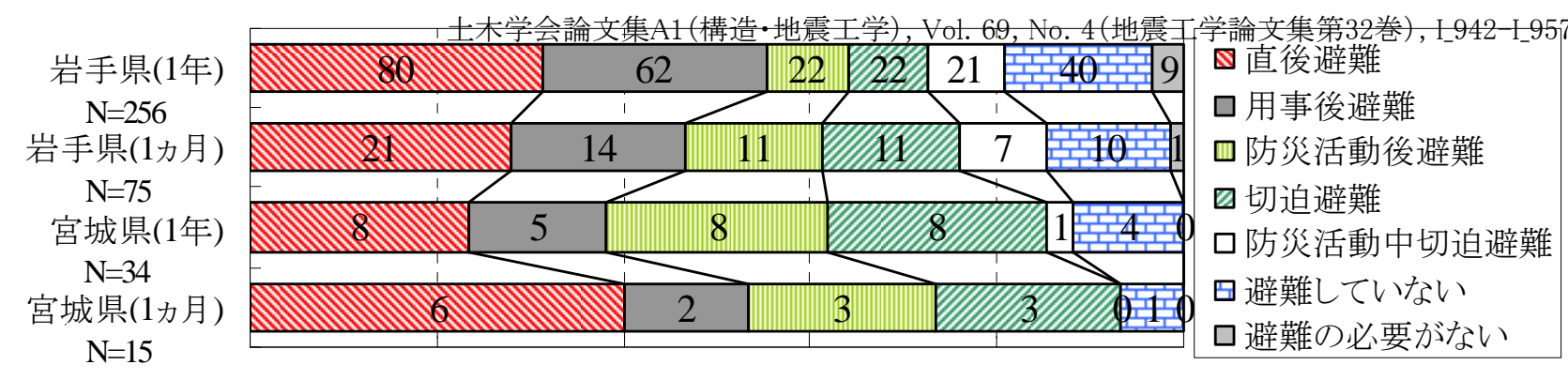

$\begin{array}{llllll}0 \% & 20 \% & 40 \% & 60 \% & 80 \% & 100 \%\end{array}$

図-8 岩手日報における避難行動記事の異なる収集期間（1 カ月間と 1 年間）による避難行動の種類

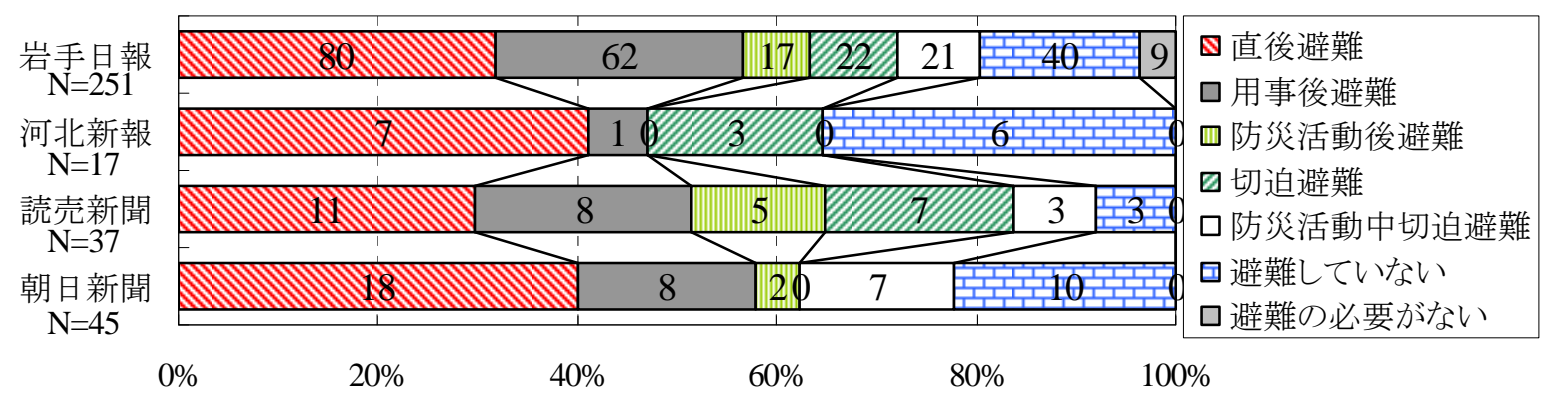

図-9 新聞別の津波避難行動記事における岩手県住民の避難行動の種類

日報における避難行動記事の異なる収集期間（1カ月と1 年間）による避難行動の種類を示す。ここでは，岩手県 と宮城県の避難行動特性を載せている. 宮城県の標本数 は，1力月分で $\mathrm{N}=16$ あるるため, 統計的に信頼性が十分 である考えられる数としての25に満たないことから信頼 性が十分だとは言えないが，岩手県（Z<1.54）でも宮城 県（Z<1.01）でも全項目で有意差はないという結果が得 られた，すなわち，収集期間の違うデータセットであっ ても, 避難行動の構成に統計的に有意な差はないことが 確認できた.

そこで以降では，岩手県ではサンプル数の多く統計的 な信頼性の高い1年間の収集期間の結果を用いるが，宮 城県では1ヶ月間のデータを用いる.

図-9に各新聞別の避難行動の種類の構成割合を示寸. 岩手日報と読売新聞には「避難の必要がない」を除いて 有意な差はない $(\mathrm{Z}<1.55)$. 岩手日報と朝日新聞には「切 迫避難」と「避難の必要がない」を除いて有意な差はな い(Z<1.26).

一方，河北新報に関しては，標本数が17であり，比率 の差の検定には不十分な数である. ただし, 統計的な有 意性を別にして「避難していない」の割合がその他の新 聞よりも高く，そのような事例に注意を喚起させようと 寸る傾向が編集方針にある可能性を除去できない.

岩手日報，読売新聞，朝日新聞の3紙を比較すると， 3 紙とも「直後避難」が一番高く, 次いで「用事後避難」
となっており，順位には大きな差異は認められない．

以上をまとめると，新聞によって事例選択に意図は感 じられるものの，統計的に有意な差異はないことがわか った，そのため，本論文では，岩手県に関しては岩手日 報を用いて岩手県住民の避難行動を分析寸る.

\section{（3） 内閣府等による避難行動調査結果との比較}

内閣府等 ${ }^{2)}$ は, 津波避難行動と被害の関係を分析し, 今後の必要な避蜼対策を進める上での資料とすることを 目的に, 平成23年東日本大震災における避難行動等に関 する面接調査を行った. 調查対象者は岩手県, 宮城県お よび福島県の沿岸地域で県内避難している被災者870名 (岩手県391名，宮城県385名，福島県94名）である. 調 查員が調査票を持参して, 調查同意者に一問一答で回答 を記録する面接方式の調査票調査である. 調査項目は, 全て被インタビュー者の避難行動であるため生き残った 人が対象になっているのに対して, 本研究では, 亡くな った人の行動が含まれることが特徵である.

なお, 内閣府の調查結果は, 岩手・宮城・福島の3県 の調查結果とその解釈が主に示されているため，3県合 計の結果の報告と思い込まれている場合もあるが，後半 に3県を区別した結果も掲載されており, 県別の解棌も 可能である. そこで，本論文では，県別や複数県の議論 は厳密に区別して，また，生き残った方と亡くなられた 方とは区別して，正当に比較している. 

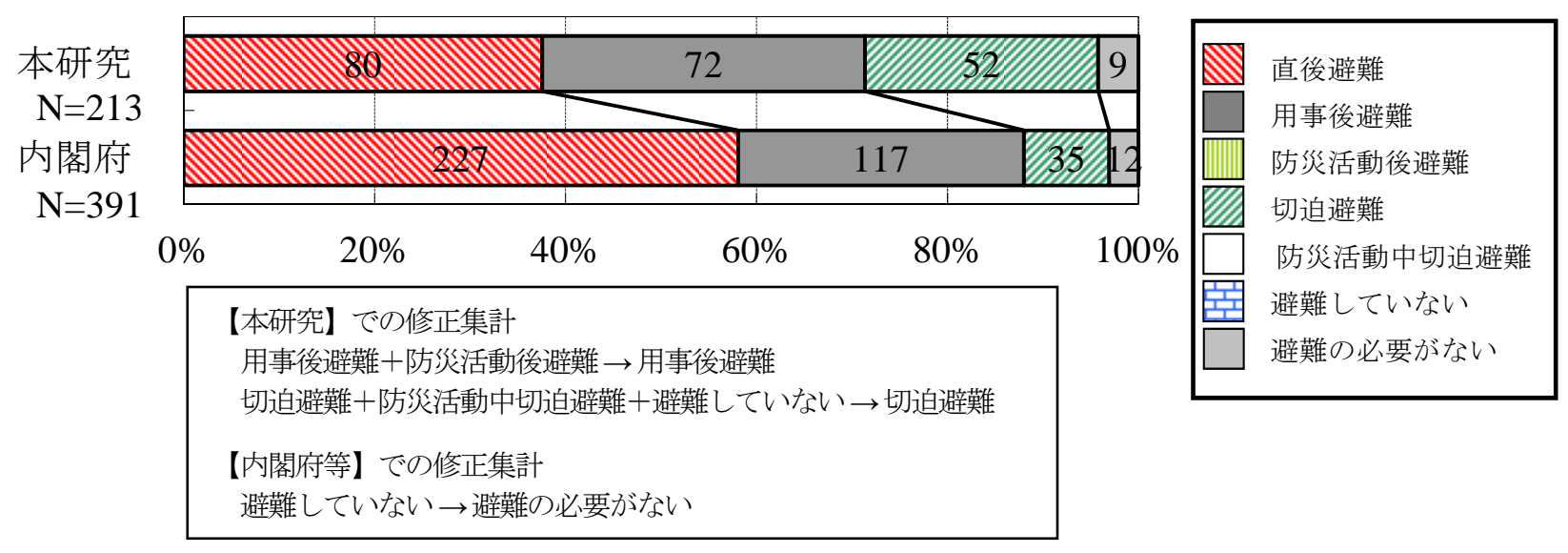

図-10 岩手県住民避難行動の種類に関する本研究（生き残った主体のみ）と内閣府調査の比較

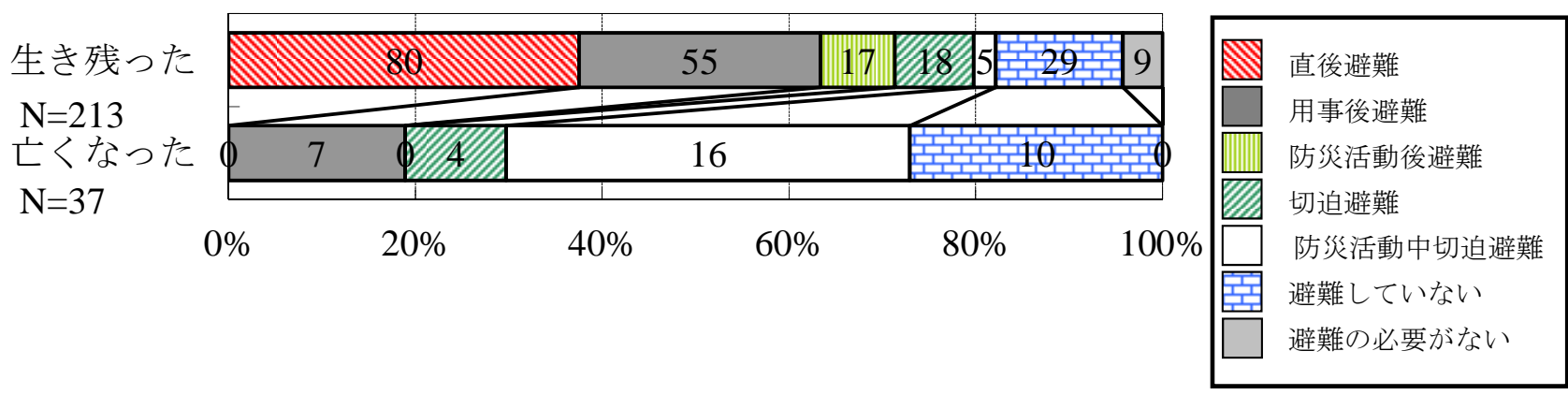

図-11 津波避難行動記事における岩手県住民の生死別避難行動の種類

図-10に避難行動の種類の構成割合に関して，岩手県 内住民の生き残った人の津波避難行動記事と内閣府等の 結果を比較して示す. 図中の数字は主体数 (回答者数) である.ただし，内閣府等の調査の分類と合わせるため に，本研究では「用事後避難」と「防災活動後避難」を 合わせて「用事後避難」に，「切迫避難」と「防災活動 中切迫避難」と「避難していない」を合わせて「切迫避 難」として集計している。また，内閣府等の分類での 「避難していない」は避難の必要がないことを意味して おり，ここでは「避難の必要がない」で計数した.

「直後避難」が本研究(37\%)よりも内閣府(58\%)の方 が有意に高い $(\mathrm{Z}=5.01)$. また，「切迫避難」は本研究 (25\%)の方が内閣府(9\%)よりも有意に高い $(\mathrm{Z}=4.74)$. その 他の分類においては差は見られない $(Z<1.01)$. そのため, 「直後避難」と「切迫避難」は相補関係となっている. 内閣府調查に比べて新聞記事調査の方が，切迫避難の 割合が高く（16ポイント），直後避難の割合が低い（21 ポイント）という結果は，3.(1)で前述した男女構成比 の差 (20ポイント) に起因することが主要因であると考 えられる.この男女比の違いを生んだ原因は，地元に密 着した新聞記者による場所を問わない取材と国行政によ る避難所訪問調査の違いや，インタビュアーとインタビ ユイーの心的距離に依存する標本の偏りの差に起因する 可能性がある.いずれにせよ，男女比が偏っているとい
う標本の違いに起因する避難行動の分析結果の偏りがあ ることを両者の調査の双方で留意する必要がある.

\section{（4）生死別の津波避難行動の比較}

生死別の津波避難行動の比較は, 内閣府調査の結果で は不可能であるが，本調査では可能である. 図-11に岩 手県の生死別の避難行動の種類を示す（合計 $\mathrm{N}=249 ）$. これは避難行動と生死の因果関係を示すものではないが, 生き残つた者と亡くなった者で, 避難行動の種類の構成 割合が全く異なる.

\section{a) 事前避難}

「直後避難」，「用事後避難」，「防災活動後避難」 を合わせたものを事前避難ということにするが，その割 合が，生き残った主体では71\%，亡くなった者では19\% と大きな差がある(Z=7.32). なかでも亡くなった者に 「直後避難」は無く, 事前避難は極めて有効であり, 地 震の摇れ直後に逃げることは津波リスクをほぼ回避でき ている.

\section{b）非避難（避難しない）}

「切迫避難」, 「防災活動中切迫避難」, 「避難せ ず」を合わせた非避難の割合が生き残った者では25\%, 亡くなった者では81 \%と大きな差がある(Z=8.00). 津波 による死亡原因は「事前に避難しないこと」だと言える. また，生き残った者の $25 \%$ の非避難者の体験は，今後, 


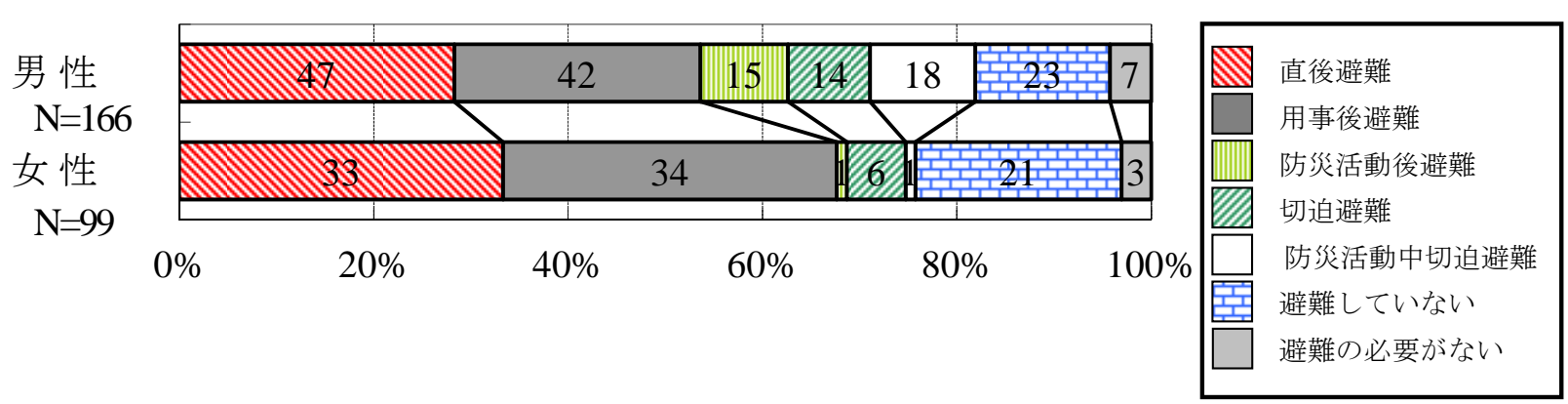

図-12 津波避難行動記事における岩手県住民の男女別避難行動の種類

避難しないでも生き残るという確証バイアス ${ }^{21)}$ に囚われ る人の根拠となりうる.

\section{c）防災活動（避難誘導）}

防災活動を行なっていたのは生死合わせて全249中, 38主体である，その内，約4割が消防団である（前述） ので，消防団に重きを置いたデータセットとなっている ことに注意が必要である. 防災活動を行っていた者の内, 「防災活動中切迫避難」21主体(55\%)の内，16主体(42\%) が死亡し，5主体(13\%)が生き延びた。この行動種類での 死亡割合は76\%となる。一方，「防災活動後避難」の 45\%は自らの避難に切り替えられ亡くなった者は皆無で ある．防災活動に区切りをつけて避難するという制御さ れた行動では難を避け得ると考えられる.

防災活動に参加するという範疇の多くが消防団活動や 自主防災活動であるが，前者に対する現地や別地でのイ ンタビュー調査の結果，異口同音に「避難誘導を途中で 打ち切ることなど考えたことがない」という反応を考え れば，防災活動に携わる者でも津波被災リスクを考慮し 区切りをつけて避難することが当然と考える客観的な視 座は，当事者は必ずしも持っていないと考えられる，そ の反省として，この津波の後に防災活動に対する消極化 が一部で唱えられているが，悲観バイアスに陥っている と見ることもできる.

したがって，地域の防災活動にとって不可欠な避難誘 導に携わる者の安全確保のためには，防災活動に終了に 関する時間を明示的に制御する制度の導入が不可欠であ る. この提案の新規性は不明であるが，この分析を通し て確認できたことは間違いない.この制度では，撤収時 間の妥当な設定方法に対する議論こそが今後の課題であ 万.

\section{d) 避難形態再考}

「切迫避難」の構成割合は，生き残った主体(8\%)と 亡くなった主体(10\%)で有意な差はない $(\mathrm{Z}=0.43)$ が，「防 災活動中切迫避難」は生き残った主体での構成割合 (2％)よりも，亡くなった主体での構成割合(43\%)の方が 有意に高い $(\mathrm{Z}=5.00)$.

防災活動に係わる避難種類は，消防団に重きを置いた
データセットになっているため，これらの避難種類を除 いて集計すると，直後避難は生き残つた主体のみであり， 用事後避難, 切迫避難, 避難せずの割合は, 生き残った 者で29\%, 10\%,5\%であるのに対して,亡くなった者では 33\%, 19\%, 48\%である. これらの3つの比率の差は全て有 意ではない（Z=0.15, 0.47, 1.93）。また，用事後避難と切 迫避難は生死両方で割合に有意な差はない. すなわち, 生死の結果という観点から見れば，用事後避難は切迫避 難と等価な避難行動である.このことは，人は目先の損 失の方を大きく見積もるという心理を表す認知心理学で 言うプロスペクト理論で説明が可能であり，用事をして から避難しても間に合うと考える確証バイアスに陥るこ とがわかる. したがって, 防災活動に係わる避難種類を 除けば，直前避難のみが有意な差である.

切迫避難と避難せずを合わせて「事前に避難しないこ と」は，生死で $67 \%, 25 \%$ となり，有意な差である

（Z=3.03）.したがって，事前避難が極めて有効であり， 事前避難しないことは津波による死亡につながる行動で あると言える.このことは, 結果が生死に別れた主体の 行動を比較して初めて明らかにしたことであり，内閣府 調査のような生き残った人で避難所にいる人のみを対象 とした調査では知り得ない. 新聞記事によるゆえの論理 的に潜在する選択的記事構成の指摘の可能性によって否 定されるものではなく，極めて重要な知見である.

以上を総合すると, ここでの考察は, 男性の避難行動 形態で女性より卓越する防災活動に係わる避難種類を除 いているので，男女に関わらず，事前避難のみが有効で あり，結果の生死という観点から見たとき，用事後避難 は切迫避難と等価であると言える.

また，男女比で僅かに男性側に僅かに偏っているとい う本調査のサンプルの特徵も行動の形態に対する細やか な検討により以上の考察が可能になったが, 内閣府調査 結果ではそのような考察はできないと考えられる.

\section{（5）男女別の津波避難行動の比較}

図-12に岩手県の男女別の避難行動の種類を示す。男 女間において差が現れているのは，「防災活動後避難」 
（男性9％，女性1\%，Z=3.28）と「防災活動中切迫避 難」（男性10\%，女性1\%，Z=3.76）である．その他の 分類は全て Z<1.57となり，有意な差は現れていない.

森 ${ }^{15}$, 森・松浦 ${ }^{10}$ は約400人に対するインタビュー調 查で明らかにした2010年チリ地震津波の避蜼行動で，男 性は防災活動などの社会的な役割を付与されることが避 難行動に結びつくことを明らかにしたが，防災活動に携 わっていたのが男性19\%, 女性2\%であるという形で, 男性の優勢な防災活動が今回の行動でも確認された。

このことは，防災活動中に亡くなったものの割合の高 さが災害後に話題になったが，この割合の高さは実数を 基にしており，新聞記事の多さで測られたものではない. しかし，実数と新聞記事数の割合に有意な差が無くても， メッセージ性を打ち出すために選択的に取り上げること が多いという新聞の特性から, 岩手日報の新聞記事構成 にもその一般特性を当てはめて, 避難行動記事でも話題 になる避難行動形態に選択的な記事構成をしているとい う指摘も考えられる. しかし，ここで示した考察によっ て, 新聞記事調査で䀣念される一定のメッセージを指向 する編集者による選択的な記事構成によるバイアスへの 懸念は岩手日報の記事構成にはなかった可能性が大きい ことが，ある程度示されたと言える。

\section{4．＼cjkstart新聞記事による宮城県住民の津波避難行動}

\section{（1） 河北新報の避難行動記事の標本の特性}

本節では男女と年齢の構成比に着目して標本の特性を 述べる. 津波避難行動記事の対象である宮城県沿岸部12 市町について2010年国勢調查に基づき集計したものを対 象とする. 図-13に (a) 国勢調査に基づく対象地域と (b) 津波避難行動記事（河北新報）における標本の男女構成 比を示す．前者が男女とも50\%であるのに対して，後者 は男性66 \%と女性34 \%の約2倍となり男性側に偏った標 本である. 一方, 内閣府調査の男女構成比は宮城県でも 4:6となり，やや女性側に偏った標本である.

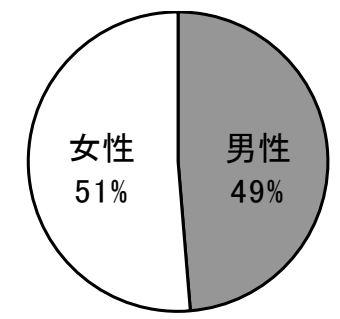

(a) 国勢調査

$(\mathrm{N}=1,691,850)$

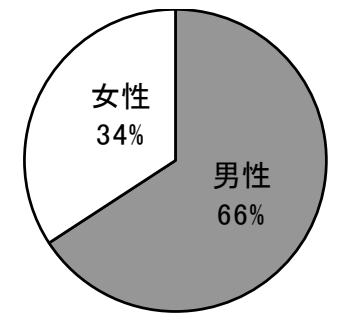

(b) 津波避難行動新聞記事

$(\mathrm{N}=85)$
図-13 宮城県の沿岸部 12 市町の男女構成比

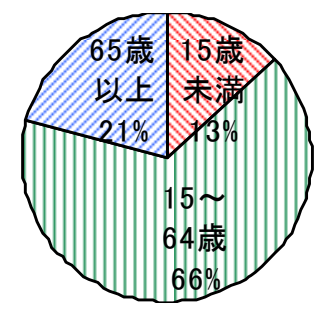

(a) 国勢調査 $(\mathrm{N}=1,655,611)$

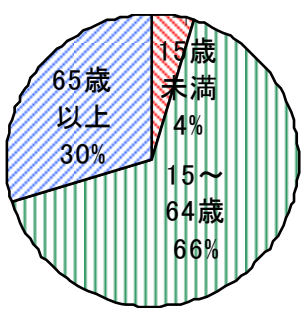

(b) 津波避難行動記事 $(\mathrm{N}=67)$
図-14 宮城県の沿岸部 12 市町の年齢別構成比

図-14に (a) 国勢調査に基づく対象地域と (b) 津波避難 行動記事（河北新報）における標本の年齢別構成比を示 す. 標本の15歳未満4 \%が母集団の $13 \%$ と比べて低くな っており, 標本の65歳以上 $30 \%$ \%集団の $21 \%$ と比べて 高くなっている.

\section{（2） 河北新報とその他の新聞との比較}

図-15に各新聞別の避難行動の種類の構成割合を示寸. サンプル数の最も多い河北新報では，「直後避難」，

「用事後避難」, 「切迫避難」の順であり, 他の3紙で は順序は様々であり, これらのデータの取り扱いには統 計的な有意性の検討が欠かせない，河北新報と岩手日報 には全ての項目において有意な差はない $(\mathrm{Z}<1.65)$. 河北 新報と読売新聞には「避難していない」を除いて有意な

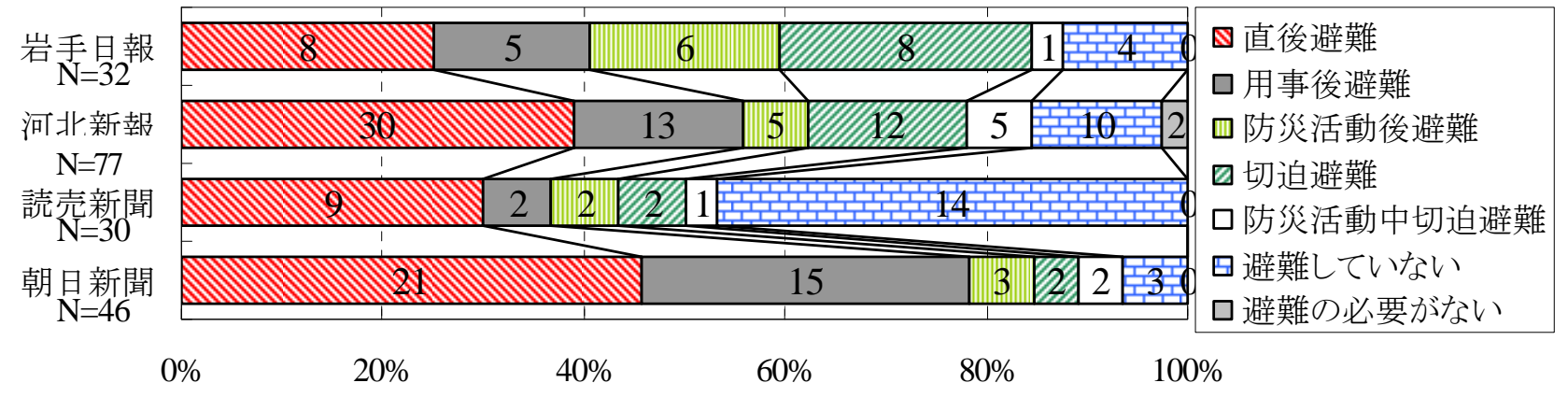

図-15 新聞別の津波避難行動記事における宮城県住民の避難行動の種類 

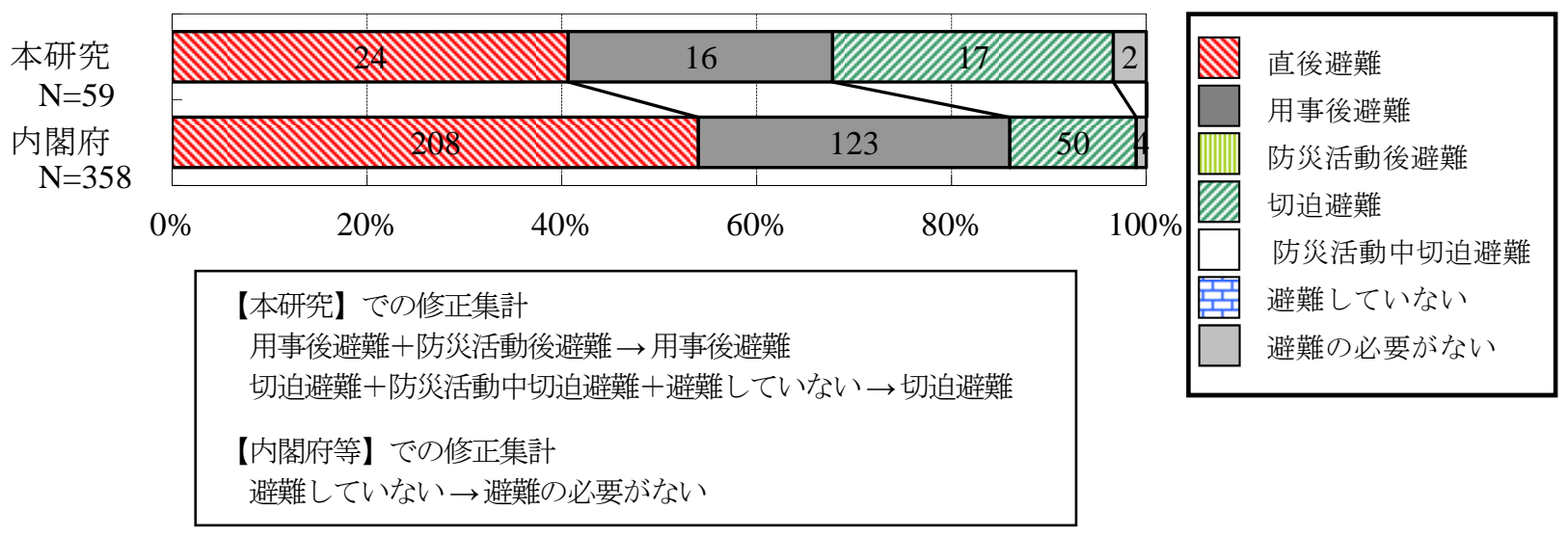

図-16 宮城県住民避難行動の種類に関する本研究（生き残った主体のみ）と内閣府調査の比較

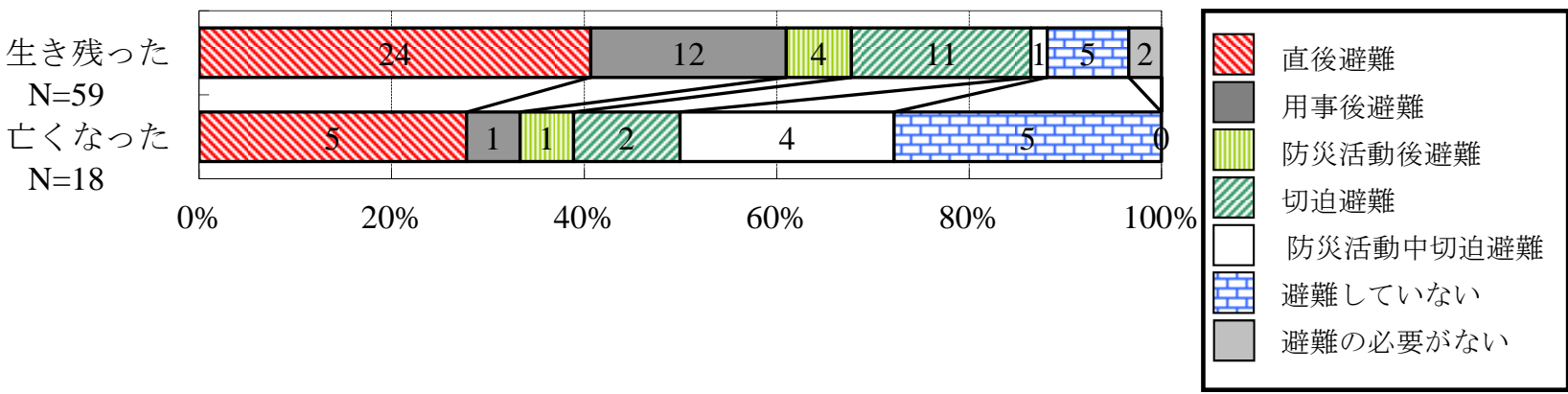

図-17 津波避難行動記事における宮城県住民の生死別避難行動の種類

差はない $(\mathrm{Z}<1.64)$. 河北新報と朝日新聞には「用事後避 難」を除いて有意な差はない $(\mathrm{Z}<1.94)$.

すなわち，読売新聞では「避難していない」が，朝日 新聞では「用事後避難」が，河北新報（や岩手日報）よ りも有意に多く取り上げられていると指摘できる.これ は，新聞社の編集意図が現れていると言える。したがっ て，これらの新聞社の編集意図が反映されたデータセッ 卜は偏った統計資料であると言える。

以上の検討に基づいて, 最もサンプル数が多く, 自ら の地方の実態を明らかにしようとする地元紙一紙を代表 とすることとし, 宮城県に関しては河北新報における宮 城県の避難行動の種類を分析対象とする.

\section{（3） 内閣府等による避難行動調査結果との比較}

図-16に避難行動の種類の構成割合に関して, 宮城県 内住民の生き残った人の津波避難行動記事と内閣府等の 結果を比較して示寸. 図中の数字は主体数 (回答者数) である. ただし，内閣府等の調査の分類と合わせるため に図-8と同様の処理をしている.

「直後避難」が本研究(41 \%)よりも内閣府(54\%)の方 が高いが有意な差ではない(Z=1.94). しかし，「切迫避 難」は本研究(29\%)の方が内閣府(13\%)よりも有意に高 い(Z=2.58). その他の分類においては差は見られない
$(\mathrm{Z}<0.97)$. 岩手日報と同様に, 地元に密着した新聞記者 による取材と国行政による調查では, インタビュアーと インタビュイーの心的距離に依存する標本の偏りの差に 起因する可能性がある.

\section{（4）生死別の津波避難行動の比較}

図-17に宮城県の生死別の避難行動の種類を示寸（合 計 $\mathrm{N}=77$ ）. 亡くなった主体の標本数が18と少ないこと に信頼性の点で十分ではなく, また，これは避難行動と 生死の因果関係を示寸ものではないものの, 生き残った 者と亡くなった者で, 避難行動の種類の構成割合が全く 異なることがわかる.

\section{a) 事前避難}

「直後避難」，「用事後避難」，「防災活動後避難」 を合わせた事前避難の割合が，生き残った主体では68％, 亡くなった者では39 \%と差がある(Z=2.22). 岩手県とは 異なり,「直後避難」でも亡くなっている.「直後避 難」で亡くなった5主体の行動では，4主体が避難した場 所で津波に遭遇しており, 1主体は要介護者で避難途中 での遭遇であった，そのため，事前避難は有効ではある が, 避難する場所の選択を十分に考慮する必要がある.

b) 非避難（避難しない）

「切迫避難」, 「防災活動中切迫避難」, 「避難せ 

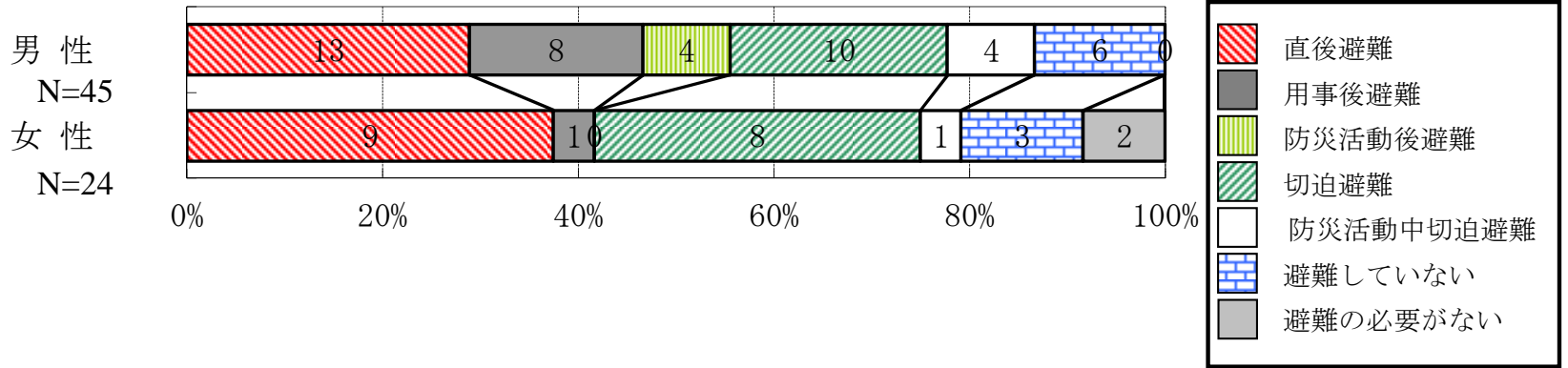

図-18＼cjkstart津波避難行動記事における宮城県住民の男女別避難行動の種類

ず」を合わせた非避難の割合が生き残った者では29\%, 亡くなった者では61 \%と大きな差がある(Z=2.50). 岩手 県と同様に，津波による死亡原因は「事前に避難しない こと」だと言え，生き残った者の $29 \%$ \%非避難者の体験 は，避難しないでも生き残るという確証バイアスに囚わ れる人の根拠となりうる.

\section{（5）男女別の津波避難行動の比較}

図-18に宮城県の男女別の避難行動の種類を示寸.女 性の主体の標本数が24であり，25未満ではあるが信頼性 はあると考えてよい，男女間において差が現れているの は，「防災活動後避難」（男性9％，女性0％， Z=2.10) である．その他の分類は全て Z $<1.94$ となり，有意な差は 現れていない. 防災活動に携わっていたのは男性18\%, 女性4 \%であり，岩手県と同様に，男性の優勢な防災活 動が今回の行動でも確認された.

また，岩手県と同様に宮城県でも，防災活動以外の項 目では男女差が認められないことは，避難行動の一般代 表性という観点から注目に值する。

\section{5. 岩手県と宮城県住民の津波避難行動の比較}

\section{（1）生死別避難行動}

図-11と図-17より，生き残った主体の避難行動に有意 な差はない $(\mathrm{Z}<1.83)$ 。また，「直後避難」，「用事後避 難」，「防災活動後避難」を合わせた事前避難の割合が， 両県において約7割である。ささらに，「直後避難」，

「用事後避難」，「防災活動後避難」の割合が，岩手県 では，37\%，26\%，8\%であり，宮城県では41％，20\%， 7 \%であるため, 地域によらず避難のタイミングの早い ほど生き残っていることがわかる.

亡くなった主体については, 宮城県の主体の標本数が 18と少ないことに信頼性の点で十分ではないが，「直後 避難」の割合が，岩手県では0％，宮城県では28 \%と差 がある(Z=2.63). その他の分類においては差は見られな い(Z<1.65).
宮城県では「直後避難」にもかかわらず亡くなった主 体の割合が高い. 地形的な観点から見ると，宮城県と岩 手県では沿岸部の地形に差があり, 厳密に言えば, 牡鹿 半島を境界に北がリアス式，南が平野であるが，おおよ そ, 岩手県はリアス式海岸, 宮城県は平野と大別できる. そのため, 高台への避難は難しく, 高い建物への避難し か選択肢が無いことが挙げられる.

さらに, 津波被害の経験という意味では, 岩手県が 「津波常習地帯」であると言われているほど歴史的に比 較的短い間隔で津波被害を受けているために津波リスク センスが相対的に高いと考えられるが，一方，宮城県で は，380余年前の慶長津波による大きな津波災害が忘れ 去られていることを警告していた飯沼 ${ }^{22)}$ が指摘するよう に，「仙台地方の沿岸の方々は」「残念なことにこうし た津波災害に対する認識は全く無いといってよい」と見 られることから，津波リスクを十分に認識できていなか ったのではないかと考えられる.

このように地形的な理由とそれにも増して, 津波災害 の時間間隔がより大きく, 前の津波災害より時間が経過 しているために醸成された低い津波リスクセンスのため に, 宮城県では「直後避難」にもかかわ的らず亡くなった 主体の割合が高かったと言える. そうであるとすれば, 認知心理学的には, 利用可能性ヒューリスティックス ${ }^{21)}$ を用いたための行動の結果と理解することができる.

また, 「切迫避難」,「防災活動中切迫避難」, 「避 難せず」を合わせた非避難の割合が岩手県では81％, 宮 城県では61\%と差があるが有意な差ではない(Z=1.52).

したがって，地域によらず津波による死亡原因は「事 前に避難しないこと」だと言え，一般に言われているこ とが新聞記事の統計分析でも確認された。

\section{（2）男女別避難行動}

図-12と図-18より, 男性の避難行動では「切迫避難」 の割合が，岩手県では8％，宮城県では22 \%と差がある (Z=2.09). 「避難の必要がない」の割合が，岩手県では 4 \%, 宮城県では0 \%と差がある(Z=2.70). その他の分類 においては差は見られない $(Z<1.16)$.女性については, 
宮城県の主体の標本数が24であり，25未満ではあるが信 頼性はあると考えてよい，女性の避難行動では「用事後 避難」の割合が，岩手県では35％，宮城県では4 \%と差 がある(Z=4.84).「切迫避難」の割合が，岩手県では6\%， 宮城県では33 \%と差がある(Z=2.74). その他の分類にお いては差は見られない(Z<1.12).

すなわち，岩手県では，女性の「用事後避難」の割合 が高く, 岩手県の特徴である. また，宮城県では男女と もに「切迫避難」の割合が高く, 宮城県の特徴である.

\section{6. 結 論}

津波避難行動に関する新聞記事を用いた内容分析によ り，岩手県と宮城県の住民の津波避難行動を統計的に明 らかにした，岩手県については，岩手日報に掲載された 避難行動主体を分析し，宮城県については，河北新報に 掲載された主体を分析した.

（1）岩手日報では，津波避難行動記事（N=348）は，地 震後 2 力月を境に掲載ペースが落ちるが，年間を通 じて一定の割合が保持され，約 7 割が 2 ケ月以降に 掲載されていた。避難行動は，災害の発生から復 旧・復興の全過程に係わる新聞記事に不可欠な事項 であると理解できる.

（2）男女比と年齢構成について，岩手日報における岩手 県の避難行動主体の標本は 6:4 であり，母数（国勢 調査) の 5:5 と比べ，男性にやや偏りがあるが，年 齢構成はほぼ同じであった。一方，河北新報におけ る宮城県の標本は 2:1 であり, 母数と比べ男性に相 当の偏りがあり，また，年齢構成は 65 歳以上が多 く, 15 歳未満が少なくなっていた. また, 内閣府 調查では，岩手県，宮城県の双方で男女比が 4:6 で あり，逆に同程度の偏りがあった。

(3) 内閣府等の調査と比較して, 新聞記事調査の方が, 岩手県，宮城県ともに切迫避難の割合が高く（16 ポイント），直後避難の割合が低い（21 ポイン ト）という結果で，これらの避難行動形態に相互に 相補関係が見られた。 これは，男女構成比の差（20 ポイント）に起因寸ることが主要因であると考えら れ，この標本の違いに起因寸る避難行動分析結果の 偏りがあることを両者の調査で留意する必要がある。

（4）避難行動記事から読み取り易い項目は，避難行動の 開始・終了時の心理と行動の事実認知に関する項目 であり，逆に読み取りにくい傾向にある項目は，避 難行動開始後の自己の心理と時空間に関する事実認 識に関する項目である.

（5）岩手日報に掲載された岩手県内の避難行動記事分析 によれば，男女に関わらず，事前避難のみが有効で
あり，結果の生死という観点から見たとき，用事後 避難は切迫避難と等価であると言える.

（6）岩手日報に掲載された岩手県の避難行動記事記事分 析では，防災活動を行って「防災活動中切迫避難」 となった 55\%の内， 42 \%が死亡し，13\%が生き延び られ，この行動形態での死亡割合は 76\%となる. 一 方, 「防災活動後避難」の 45\%は自らの避難に切り 替えられ亡くなった者は皆無である.このことから， 防災活動に区切りをつけて避難するという制御され た行動では難を避け得ることが定量的に確認できた. 本研究においても避難誘導などの防災活動には明示 的時間管理の制度が必要であることを確認した。

(7) 岩手日報に掲載された岩手県の記事では防災活動に

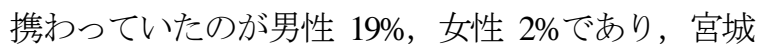
県では，男性 18\%，女性 $4 \%$ であった. チリ地震津 波避難行動調査での知見が，男性の優勢な防災活動 という形で確認された。

（8）宮城県では「直後避難」にもかかわらず亡くなった 主体の割合が高い，岩手県がリアス式海岸であるの に対して, 宮城県は平野であり, 高い建物への避難 しか選択肢が無いことが挙げられる．また，津波被 害の経験という観点からは，宮城県では約400年前 の慶長津波災害が忘れ去られ, 醸成された低い津波 リスクセンスのせいで津波リスクを十分に認識でき ていなかった人の心理が原因と推量される.

謝辞 良く読み込まれたうえで示唆に富むご意見を戴い た査読者に心より感謝いたします。著者らの議論を深め 論点を一層明快にし, 原稿を改善するのに有用でした.

\section{参考文献}

1) 警察庁: 平成 23 年(2011 年)東北地方太平洋沖地震の被害 状況と警察措置, 2012年 9 月 12 日,

http://www.npa.go.jp/archive/keibi/biki/higaijokyo.pdf (2012.11.10 閲覧)

2) 内閣府, 消防庁, 気像庁: 平成 23 年東日本大震災におけ る避難行動等に関する面接調查(住民)分析結果,

http:/www.bousai.go.jp/jishin/chubou/higashinihon/7/1.pdf (2012.11.10 閲覧)

3) 谷 富夫, 芦田徹朗：よくわかる質的社会調查技法編（初 版第 2刷)，pp. 120-133, ミネルヴァ書房, 2010.

4) クリッペンドルフ，K：メッセージ分析の技法（1 版 2 刷)， pp.7-20, pp.21-35, pp. 202-265, 勁草書房, 1992.

5) 鈴木裕久 : マス・コミュニケーションの調查研究法, pp. 89107, 創風社, 1990.

6) 東京大学新聞研究所 : 災害と人間行動, pp. 125-154, 東京大 学出版会, 1982.

7) 安倍 北夫, 三隅二不二, 岡部慶三 : 応用心理学講座 3 自 
然㷋害の行動科学, pp. 123-167, 福村出版株式会社, 1988.

8）寄藤 昂，中山 裕未 : 新聞報道が描く“被災者”像と被災 地の社会構造との乘離について,

http:/tohokugeo.jp/disaster/articles/j-contents11.pdf

(2013.2.10 閲覽)

9) 荒牧 軍治，古賀 勝喜，高田 哲治 : 新聞記事に見る阪神大 震災の影響分析，土木学会第52回年次学術講演会講演概 要集第1部, Vol.52, pp.842-843, 1997.

10）五味 千絵子, 葛葉 泰久 : 新聞記事を基とした避難行動調 查～東日本大震災を例として〜，日本自然災害学会学術 講演会講演概要集, Vol.31, pp. 7-8, 2012.

11）鵜久森 潤,森伸一郎：2011年東北地方太平洋沖地震津波に おける住民の避難行動に見られる地域差, 地域安全学会梗 概集, No.30, pp.47-50, 2012.

12) 森 伸一郎，鵜久森 潤 : 2011年東北地方太平洋沖地震津波 における住民の避難行動に見られる男女間の差異, 地域安 全学会梗概集, No.30, pp.41-46, 2012.

13) 森 伸一郎, 鵜久森 潤 : 東北地方太平洋沖地震の津波少 クに対する住民の避難行動時期, 地域安全学会東日本大震 災特別論文集, No.1, pp.19-22, 2012.

14) ティム・メイ : 社会調査の考え方一論点と方法一, pp. 271294, 世界思想社, 2005.
15) 森 伸一郎 : 5.5 四国における沿岸住民の避難行動の実態, 「2010 年 2 月チリ中部沿岸を震源とする地震」による津 波への四国地域防災行動調査報告書，四国における地 震・津波対策アドバイザリー会議, 国土交通省四国地方 整備局企画部, pp. 144-193, 2011.

16）森 伸一郎，松浦 尚輝 : 2010年チリ地震津波に対する住民 の避難トリガー,地域安全学会梗概集, No.28, pp. 57-60, 2011.

17) 稲垣宣生, 山根芳知, 吉田光雄 : 統計学入門, 第22版, pp. 139-140, 裳華房, 2009.

18）岩手県政策地域部：岩手県の人口と世帯，2011年3月25日

19) 宮城県統計課 : 宮城県推定人口，2011年3月1日

20) 福島県企画調整部統計調査課 : 福島県の推定人口，2011年 10月5日

21) Tversky, A. and Kahneman, D. : Judgment under Uncertainty: Heuristics and Biases, Science, New Series, Vol. 185, No. 4157, pp. 1124-1131, 1974.

22）飯沼 勇義 : 仙台地方の歴史津波, 復刻版, pp.21, 2011.（初 版1995)

(2012.11.16 受付, 2013.3.20. 修正, 2013.3.22. 受理)

\title{
RESIDENT EVACUATION FROM TSUNAMIS DURING THE 2011 GREAT EAST JAPAN EARTHQUAKE BASED ON CONTENT ANALYSIS ON NEWSPAPER ARTICLES
}

\author{
Shinichiro MORI and Jun UGUMORI
}

Pacific-coastal areas of Tohoku region were totally swept by the devastating tsunamis triggered by the 2011 Great East Japan Earthquake. Almost all of some nineteen thousands victims were killed due to drowning in the tunamis. In order to clarify the actual situations of residential evacuation from tsunami risks anticipated after the quake, we collected 509 newspaper articles related to resident's tsunami evacuation and conducted content analysis on them. Focusing Iwate and Miyagi Prefectures, appropriate and inappropriate evacuation timing are statistically discussed from the viewpoint of difference between survivers and victims, and so on. Immediate evacuation is statistically confirmed to be only successful way to survive based on Iwate News Paper. We can say that evacuation leading requires some time control. 